\title{
Carbonate-bonded construction materials from alkaline residues
}

\author{
Peter Nielsen ${ }^{a}$, Renato Baciocchi ${ }^{\mathrm{b}}$, Giulia Costa ${ }^{\mathrm{b}}$, Mieke Quaghebeur ${ }^{\mathrm{a}}$, Ruben Snellings ${ }^{\mathrm{a},{ }^{*}}$ \\ a Sustainable Materials Management, VITO - Flemish Institute for Technological Research, Mol, Belgium \\ b Laboratory of Environmental Engineering, Department of Civil Engineering and Computer Science Engineering - University of Rome "Tor \\ Vergata", Via del Politecnico 1, Rome, Italy
}

Received: 15 December 2017 / Accepted: 28 December 2017 / Published online: 30 December 2017

(C) The Author(s) 2017. This article is published with open access and licensed under a Creative Commons Attribution 4.0 International License.

\begin{abstract}
Accelerated carbonation is a rapidly developing technology that is attracting attention as it uses $\mathrm{CO}_{2}$ as a binder to make construction materials. Originally stemming from geochemical and environmental research into $\mathrm{CO}_{2}$ sequestration or waste remediation, accelerated carbonation has been developed into a technology that enables to transform alkaline precursors into products that meet technical requirements for use as aggregates or shaped blocks. Alkaline precursors can be manufactured from primary resources or derived from industrial residues: a.o. metallurgical slags, incineration ashes and concrete recycling residues are prone to carbonate under controlled conditions. Moist carbonation of shaped Ca-silicate rich precursors at elevated curing temperature and $\mathrm{CO}_{2}$ concentration or pressure has delivered the most promising results so far.

This letter presents an overview of current accelerated carbonation approaches to make carbonate-bonded construction materials from alkaline residues. The general carbonation mechanism is explained and two application routes are exemplified: i.e. production of lightweight aggregates and compact blocks by accelerated moist carbonation.
\end{abstract}

Keywords: Carbonation; Slags; CO2; Aggregates; Compacts; Curing

\section{Introduction}

Among low carbon cements, by far the greatest $\mathrm{CO}_{2}$ reduction potential is offered by cements that actually sequester $\mathrm{CO}_{2}$ as solid carbonates as part of their solidification process [1,2]. "Carbonate-bonded" construction materials actually mimick their natural limestone counterparts $[3,4]$. The abundance of limestones in the geological record and their use as traditional building material indicate the potential for long-term durability and preservation of technical quality [5].

In the context of concrete, carbonation is mostly perceived as problematic as it is one of the prime causes of deterioration of reinforced concrete structures by corrosion [6]. In case carbonation is actually desirable then kinetic barriers that slow down the natural carbonation process need to be overcome by applying elevated temperature and $\mathrm{CO}_{2}$ concentrations in curing chambers or autoclaves. Chemicals such as $\mathrm{NaOH}$ can be added to accelerate and enhance the process even further [7]. Most recent research developments in producing $\mathrm{CO}_{2}$ uptake cements depart from calcium (and magnesium)-rich materials and relate to 1 ) accelerated curing of concrete [8-10], 2) carbonation of brines [11-13], 3) carbonation of hydrated lime [14,15] and 4) carbonation of calcium silicates [16-19].

Although in principle similar mechanisms apply for carbonation of different precursors, this review will focus on $\mathrm{Ca}(\mathrm{Mg})$ silicate based precursors, mainly because most recent progress was made in this area. The carbonation mechanism, potential precursors and examples of specific product developments are treated in the following sections.

\section{Carbonation mechanisms}

The basic concept behind carbonation of $\mathrm{Ca}(\mathrm{Mg})$-silicates is the process of rock weathering. In this natural process calcium and magnesium ions are leached from silicate rocks and react with ambient $\mathrm{CO}_{2}$ to form solid carbonates.

Direct mineral carbonation is the process in which the extraction of metal ions from $\mathrm{Ca} / \mathrm{Mg}$-rich rocks or solid residues and the precipitation of carbonate(s) take place in one process step. Indirect carbonation is accomplished through the extraction in a solution of reactive ions (generally $\mathrm{Ca}$ and/or $\mathrm{Mg}$ ) from the minerals in the first step 
and carbonation in a subsequent step as a result of the chemical reaction with either gaseous or aqueous $\mathrm{CO}_{2}[20]$. The direct carbonation route can yield a variety of valuable construction products while the indirect route, can lead to very pure Precipitated Calcium Carbonate that can find use in the papermaking industry, as a filler in polymer materials or as coating pigment to increase solar reflectance [21].

The overall carbonation chemistry in the direct carbonation route using calcium or magnesium silicates is presented in Equation 1:

$$
(\mathrm{Ca}, \mathrm{Mg})_{2} \mathrm{SiO}_{4}+\mathrm{CO}_{2}+\mathrm{H}_{2} \mathrm{O} \rightarrow 2(\mathrm{Ca}, \mathrm{Mg}) \mathrm{CO}_{3}+\mathrm{SiO}_{2}+\mathrm{H}_{2} \mathrm{O}
$$

The reaction consists of three main subprocesses (Fig. 1): (1) the diffusion of $\mathrm{CO}_{2}$ through the pore network and dissolution of $\mathrm{CO}_{2}$ in an aqueous solution to form carbonic acid; (2) the dissolution or leaching of calcium and/or magnesium from the silicates in an aqueous solution, and (3) the precipitation of calcium and/or magnesium carbonates (and silica) [22,23].

In the direct carbonation route steps (1) and (2) occur simultaneously and the rate and extent of carbonation depend on a number of factors such as the precursor composition and moisture saturation degree [24,25], but also on the carbonation conditions such as the $\mathrm{CO}_{2}$ grade and pressure and the relative humidity $[26,27]$. Saturation degree and relative humidity play a key role in providing $\mathrm{CO}_{2}$ access to the connected pore network. $\mathrm{CO}_{2}$ diffusion in the aqueous phase is slow and therefore decreases sharply in highly saturated materials, leading to incomplete carbonation. An additional factor to take into account is that the carbonation reaction of Ca-silicates is highly exothermic, e.g. the reaction enthalpy of equation (1) is about $-1300 \mathrm{~J} / \mathrm{g}$. This heat may lead to internal temperature gradients and pressure build up due to vapour generation. Crucial in product design is therefore to find mix designs and reaction conditions that well balance the ongoing processes to avoid incomplete carbonation of the product interior or failure by fracturing.

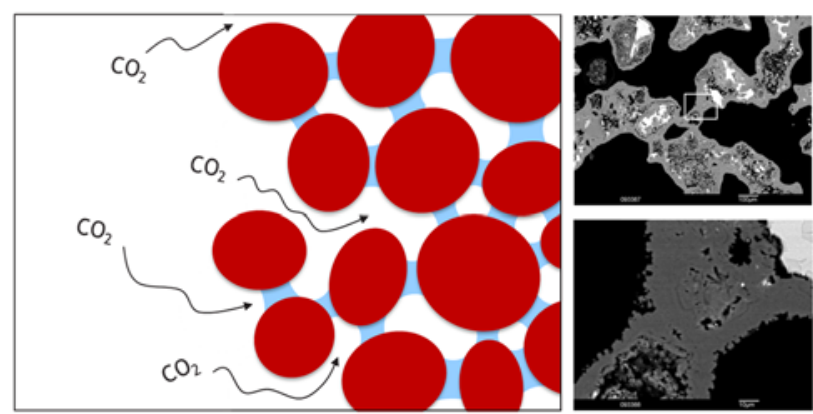

Figure 1. Moist carbonation of unsaturated compacts: schematic view (left), Backscattered electron microscopy images showing precipitation of calcium carbonates at pore necks and particle surfaces.

\section{Precursors and $\mathrm{CO}_{2}$}

The precursor $\mathrm{Ca}(\mathrm{Mg})$ silicate material can be manufactured in a conventional Portland clinker kiln using the same raw materials as required for cement. Since formation of alite is not required, kiln temperatures can be lowered to about $1150-1250^{\circ} \mathrm{C}$, saving fuel and lowering $\mathrm{CO}_{2}$ emissions additional to the $\mathrm{CO}_{2}$ uptake by subsequent carbonation. The Solidia company is upscaling this approach [28]. However, precursor manufacturing cost and emissions can be avoided if one can use carbonatable mined minerals, [29], or alkaline residues from other industries. The remainder of this letter will treat the latest developments in the latter field.

Secondary resources that can be used include in principle all alkaline waste materials rich in non-carbonated $\mathrm{CaO}$ and/or $\mathrm{MgO}$. Materials that have been considered for carbonation include ash from coal-fired power plants ( $\mathrm{CaO}$ content up to 65 wt-\%), bottom ash ( $\sim 10$ to 20 wt- $\% \mathrm{CaO}$ ) and fly ash ( 35 wt-\% $\mathrm{CaO}$ ) from municipal solid waste incinerators, de-inking ash from paper recycling ( $\sim 35$ wt-\% $\mathrm{CaO}$ ), steelmaking slag ( $\sim 30-60$ wt-\% $\mathrm{CaO}$ and $\mathrm{MgO})$, and waste cement or concrete [30-34].

Most research on carbonation of alkaline residues has focussed on carbonation as a means for $\mathrm{CO}_{2}$ sequestration, immobilising toxic elements and heavy metals, as well as improving the structural durability of wastes and byproducts [20]. Far fewer research has been carried out with the purpose of using accelerated carbonation to make construction materials [17,35-37]. Tables 1 and 2 summarize reports in the scientific literature on accelerated carbonation as a means to produce carbonate bonded blocks (Table 1) and aggregates (Table 2) from alkaline residues. Carbonation conditions, efficiency and product performance are compared.

Because alkaline residues and wastes may contain metals and other elements that potentially pose a threat to the environment, the leaching of contaminants from the carbonated products should always be assessed. Carbonation may effectively reduce the leaching of elements such as lead and zinc but may also enhance the leaching of other elements such as chromium, vanadium, copper, sulphate and fluoride in slags or ashes [38-40].

The $\mathrm{CO}_{2}$ used in the process can be obtained from different sources: e.g. from flue gases from coal-fired power plants or from waste incineration plants, which have $\mathrm{CO}_{2}$ concentrations of 10 to $20 \%$ [41], or from biogas, which typically contains $25-55 \% \mathrm{CO}_{2}[42]$.

\section{Case 1: Carbonate bonded aggregates}

The idea of combining carbonation with an agglomerating process was first introduced by Gunning et al. [46] to valorize alkaline residues, producing aggregates with suitable properties for applications in the construction sector. The pilot-scale process (see Fig. 2) was made up of a rotary carbonation reactor (pelletizing drum) operated at ambient temperature and pressure fed by the premixed residues with quarry fines and water. The product was discharged into a curing chamber circulated with dehumidified $\mathrm{CO}_{2}$ for 7 days. Aggregates with properties comparable to natural lightweight aggregates (bulk density below $1000 \mathrm{~kg} / \mathrm{m}^{3}$ and 
pellet strength above $0.10 \mathrm{MPa}$ ) were obtained using at least $40 \%$ of alkaline residues such as Cement Kiln Dust (CKD), wood ash or paper ash.

More recently, the process at pilot-scale was tested for MSWI APCr (Air Pollution Control residues) using pure $\mathrm{CO}_{2}$
[47]. The leaching of the resulting aggregate was reduced with respect to the untreated $\mathrm{APCr}$ for most metals (e.g. Pb from 143.9 to $1.8 \mathrm{mg} / \mathrm{kg}$ ). Based on these results, the process was scaled up and is being commercialized by the Carbon8 Aggregates company [50].

Table 1. Carbonate bonded compacts (blocks): overview of investigated precursors, process conditions, efficiency and product performance.

\begin{tabular}{|c|c|c|c|c|c|c|c|c|c|c|}
\hline \multirow{2}{*}{$\begin{array}{l}\text { Material } \\
\text { Type }\end{array}$} & \multirow{2}{*}{$\begin{array}{l}\text { Composition } \\
\text { (wt.\%) }\end{array}$} & \multirow{2}{*}{$\begin{array}{c}\text { Precursor particle } \\
\text { size }\end{array}$} & \multirow{2}{*}{$\begin{array}{l}\text { Compact size } \\
\text { Compaction } \\
\text { pressure }\end{array}$} & \multicolumn{4}{|c|}{ Carbonation conditions } & \multicolumn{2}{|c|}{ Efficiency } & \multirow[b]{2}{*}{$\begin{array}{l}\text { Referen } \\
\text { ce }\end{array}$} \\
\hline & & & & $\begin{array}{l}\text { Pressure/ } \\
\mathrm{CO}_{2} \text { conc. }\end{array}$ & Temp. & $\begin{array}{l}\text { Moisture } \\
\text { content/ } \\
\mathrm{RH}\end{array}$ & duration & $\mathrm{CO}_{2}$-uptake & $\begin{array}{l}\text { Compr. } \\
\text { Strength } \\
\text { (in } \mathrm{MPa} \text { ) }\end{array}$ & \\
\hline Steel slag & $\begin{array}{l}\mathrm{CaO}: 56.8 \% \\
\mathrm{MgO}: 3.7 \%\end{array}$ & $\begin{array}{l}\text { Median } \\
\text { diameter } \\
610 \mu \mathrm{m}\end{array}$ & $\begin{array}{c}100 \mathrm{~mm} \\
\text { diamer } \times 200 \\
\mathrm{~mm} \text { heigh } \\
25 \times 25 \times 25 \mathrm{~cm} \\
1 \times 1 \times 1 \mathrm{~m} \\
\text { Bulk density: } \\
2.30 \mathrm{~g} / \mathrm{cm}^{3}\end{array}$ & $\begin{array}{l}1.005 \mathrm{~atm} \\
1 \mathrm{~L} / \mathrm{min} \\
1.030 \mathrm{~atm}\end{array}$ & & $\begin{array}{c}L / S=0.053- \\
0.063\end{array}$ & & $6 \pm 1$ weight $\%$ & $\begin{array}{c}18.3 \\
19\end{array}$ & {$[43,44]$} \\
\hline $\begin{array}{l}\text { Stainless } \\
\text { steel slag }\end{array}$ & & $<125 \mu \mathrm{m}$ & & $\begin{array}{c}0.3 \mathrm{MPa} \\
100 \% \mathrm{CO}_{2}\end{array}$ & & $\mathrm{~L} / \mathrm{S}=0.125$ & & 18 weight $\%$ & 9 & [17] \\
\hline Steel slag & $\begin{array}{l}\mathrm{CaO}: 41 \% \\
\mathrm{MgO}: 7.6 \%\end{array}$ & $5 \sim 24 \mu \mathrm{m}$ & $\begin{array}{c}90 \times 40 \times 10 \mathrm{~mm} \\
7.75 \mathrm{MPa}\end{array}$ & $\begin{array}{c}0.536 \mathrm{MPa} \\
100 \% \mathrm{CO}_{2}\end{array}$ & & $\begin{array}{c}\mathrm{L} / \mathrm{S}=0.125 \\
\mathrm{RH}: \\
60 \sim 80 \%\end{array}$ & $120 \mathrm{~min}$. & $\begin{array}{c}108 \\
\mathrm{~g} \mathrm{CO}_{2} / \mathrm{kg} \text { slag }\end{array}$ & 45 & [36] \\
\hline $\begin{array}{l}\text { Stainless } \\
\text { steel slag } \\
\text { (EAF) }\end{array}$ & $\begin{array}{l}\mathrm{CaO}: 44 \% \\
\mathrm{MgO}: 6.8 \%\end{array}$ & $<500 \mu \mathrm{m}$ & $\begin{array}{c}61 \times 61 \times 40 \mathrm{~mm} \\
17.85 \mathrm{MPa}\end{array}$ & $\begin{array}{l}2.0 \mathrm{MPa} \\
100 \% \mathrm{CO}_{2}\end{array}$ & $140^{\circ} \mathrm{C}$ & $\mathrm{L} / \mathrm{S}=0.12$ & 16 hours & $\begin{array}{c}177-188 \\
\mathrm{~g} \mathrm{CO}_{2} / \mathrm{kg} \text { slag }\end{array}$ & $\begin{array}{c}55 \\
\text { (Tensile } \\
\text { splitting } \\
\text { strength:2. } \\
7 \mathrm{MPa} \text { ) }\end{array}$ & [35] \\
\hline $\begin{array}{l}\text { Stainless } \\
\text { steel slag } \\
\text { (EAF) }\end{array}$ & $\begin{array}{l}\mathrm{CaO}: 45 \% \\
\mathrm{MgO}: 9.3 \%\end{array}$ & $\begin{array}{c}\text { 5-300 } \mu \mathrm{m} \\
\text { D50: } 100 \mu \mathrm{m}\end{array}$ & $\begin{array}{c}300 \times 100 \times 50 \\
\mathrm{~mm} \\
29.42 \mathrm{MPa} \\
\end{array}$ & $\begin{array}{c}2.0 \mathrm{Mpa}, \\
100 \% \mathrm{CO}_{2}\end{array}$ & $140^{\circ} \mathrm{C}$ & $L / S=0.10$ & 16 hours & $\begin{array}{c}150-200 \\
\mathrm{~g} \mathrm{CO}_{2} / \mathrm{kg} \text { slag }\end{array}$ & 134 & [18] \\
\hline \multirow{2}{*}{$\begin{array}{l}\text { Stainless } \\
\text { steel slag } \\
\text { (AOD) }\end{array}$} & \multirow{2}{*}{$\begin{array}{l}\mathrm{CaO}: 55 \% \\
\mathrm{MgO}: 8.0 \%\end{array}$} & \multirow{2}{*}{$\begin{array}{c}\text { 10-200 } \mu \mathrm{m} \\
\mathrm{D} 50: \sim 60 \mu \mathrm{m}\end{array}$} & \multirow{2}{*}{$\begin{array}{c}\text { 40x40x40 mm } \\
\text { Fresh bulk } \\
\text { density: } 2.25 \\
\mathrm{~g} / \mathrm{cm}^{3}\end{array}$} & $\begin{array}{l}\text { Atm. pressure } \\
5 \text { vol. } \% \mathrm{CO}_{2}\end{array}$ & $22^{\circ} \mathrm{C}$ & $\begin{array}{c}\mathrm{L} / \mathrm{S}=0.15 \\
\mathrm{RH}: 80 \%\end{array}$ & 3 weeks & 4.3 weight $\%$ & 43 & \multirow{2}{*}{ [37] } \\
\hline & & & & $\begin{array}{c}0.8 \mathrm{MPa} \\
100 \% \mathrm{CO}_{2}\end{array}$ & $80^{\circ} \mathrm{C}$ & $L / S=0.15$ & 15 hours & 8.1 weight $\%$ & 60 & \\
\hline
\end{tabular}

Table 2. Carbonate bonded aggregates: overview of investigated precursors, process conditions, efficiency and product performance reported in literature.

\begin{tabular}{|c|c|c|c|c|c|c|c|c|c|}
\hline \multirow[t]{2}{*}{ Material Type } & \multirow{2}{*}{$\begin{array}{l}\text { Composition } \\
\text { (wt.\%) }\end{array}$} & \multirow{2}{*}{$\begin{array}{c}\text { Precursor } \\
\text { particle size }\end{array}$} & \multicolumn{4}{|c|}{ Carbonation conditions } & \multicolumn{2}{|c|}{ Efficiency } & \multirow[b]{2}{*}{ Reference } \\
\hline & & & $\begin{array}{l}\text { Pressure/ } \\
\mathrm{CO}_{2} \text { conc. }\end{array}$ & Temp. & $\begin{array}{l}\text { Moisture } \\
\text { content/ RH }\end{array}$ & time & $\mathrm{CO}_{2}$-uptake & $\begin{array}{c}\text { Compr. } \\
\text { Strength } \\
\text { (in } \mathrm{N} / \mathrm{cm}^{2} \text { ) }\end{array}$ & \\
\hline Carbide slag & $\begin{array}{l}\mathrm{CaO}: 69.2 \% \\
\mathrm{MgO}: 1.1 \% \\
\end{array}$ & \multirow{4}{*}{$74-150 \mu \mathrm{m}$} & \multirow{4}{*}{$\begin{array}{l}0.6 \mathrm{MPa} / \\
100 \% \mathrm{CO}_{2}\end{array}$} & \multirow{4}{*}{$55^{\circ} \mathrm{C}$} & \multirow{4}{*}{$L / S=6$} & \multirow{4}{*}{$125 \mathrm{~min}}$. & $443 \mathrm{~g} \mathrm{CO}_{2} / \mathrm{kg}$ & 224 & \multirow{4}{*}[45]{} \\
\hline Waste lime & $\begin{array}{l}\mathrm{CaO}: 81.3 \% \\
\mathrm{MgO}:-\%\end{array}$ & & & & & & $585 \mathrm{~g} \mathrm{CO}_{2} / \mathrm{kg}$ & 277 & \\
\hline Steel slag & $\begin{array}{l}\mathrm{CaO}: 38.9 \% \\
\mathrm{MgO}: 7.6 \%\end{array}$ & & & & & & $202 \mathrm{~g} \mathrm{CO}_{2} / \mathrm{kg}$ & 198 & \\
\hline Waste concrete & $\begin{array}{l}\mathrm{CaO}: 23.5 \% \\
\mathrm{MgO}: 1.6 \%\end{array}$ & & & & & & $75 \mathrm{~g} \mathrm{CO}_{2} / \mathrm{kg}$ & 104 & \\
\hline $\begin{array}{l}\text { CKD/paper ash/ } \\
\text { wood ash/MSWI } \\
\text { APCr }\end{array}$ & $\begin{array}{l}\mathrm{CaO}: 45-70 \% \\
\mathrm{MgO}: 1-14 \%\end{array}$ & - & $\begin{array}{c}1 \mathrm{~atm} . / \\
100 \% \mathrm{CO}_{2}\end{array}$ & $22^{\circ} \mathrm{C}$ & $L / S=$ & 7 days & $3.9-8.3 \%$ & $120-170$ & {$[46,47]$} \\
\hline $\begin{array}{l}\text { Carbon steel slag } \\
\text { (BOF) }\end{array}$ & $\begin{array}{l}\mathrm{CaO}: 55 \% \\
\mathrm{MgO}: 14 \%\end{array}$ & $0.4-0.5 \mathrm{~mm}$ & $\begin{array}{c}1 \mathrm{~atm} . / 40 \% \\
\mathrm{CO}_{2}\end{array}$ & $20-50^{\circ} \mathrm{C}$ & $\mathrm{L} / \mathrm{S}=0.2$ & $30 \mathrm{~min}$. & $4-10 \%$ & - & {$[48,49]$} \\
\hline
\end{tabular}

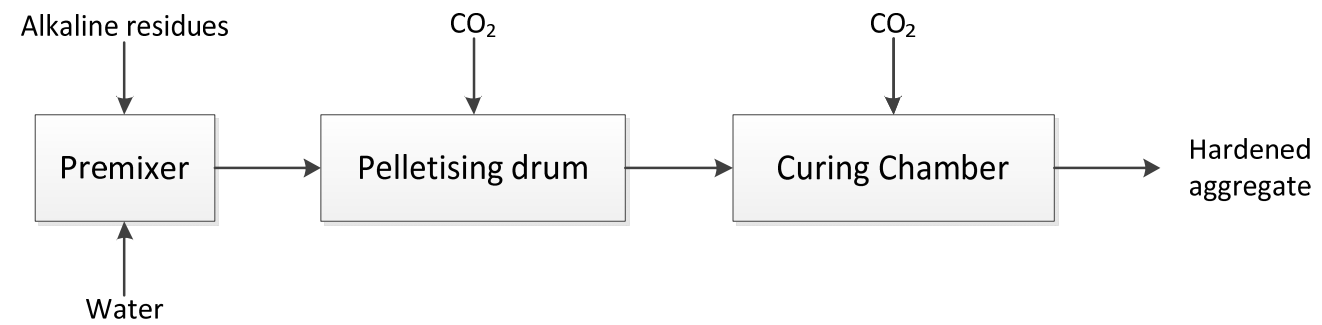

Figure 2. Scheme of a pilot-scale process proposed for aggregates production based on carbonation of industrial residues. Adapted from [46]. 
The production of carbonate-bonded aggregates from Basic Oxygen Furnace (BOF) steel slags was investigated by Morone et al. [48] in a lab-scale granulation device and more recently by the same group also in a pilot-scale rotating drum [49]. Operating at lab-scale at $40 \% \mathrm{CO}_{2}$ concentration and ambient temperature and pressure, allowed to obtain a $\mathrm{CO}_{2}$ uptake of $2.5 \%$ immediately at the end of the test (30 $\mathrm{min}$ ) and of $5.5 \%$ after 28 days curing in a moist atmosphere. [49]. A remarkably higher $\mathrm{CO}_{2}$ uptake was achieved for the pilot-scale tests performed in a rotary kiln at $40 \% \mathrm{CO}_{2}$ concentration, atmospheric pressure and temperatures of 30 or $50{ }^{\circ} \mathrm{C}$. Values between 4.4 and $6 \% \mathrm{CO}_{2}$ uptake were measured in samples collected immediately after the treatment, which increased up to $10 \%$ in some of the samples after $28 \mathrm{~d}$ curing. The increased $\mathrm{CO}_{2}$ uptake in the pilot tests was explained by the higher specific surface area of the granules exposed to the $\mathrm{CO}_{2}$ flow with respect to labscale tests [49]. Besides the potential increase of the leaching of $\mathrm{Cr}$ and other oxyanion-forming elements, the main barrier to produce carbonate-bonded aggregates according to this process was the mechanical properties. Latest developments show that for BOF steel slag this issue can be addressed by using alkaline activators although in this case the leaching of $\mathrm{Cr}$ and $\mathrm{V}$ did not comply to leaching limits for unbound use, nor did the product $\mathrm{pH}$ [51].

\section{Case 2: Carbonate bonded compacts}

Apart from $\mathrm{CO}_{2}$ sequestration and mineral stabilization, the formation of carbonates by accelerated carbonation of steel slag can also serve as a consolidation for the slag material. A typical process for direct carbonation of compacts consists of 3 main steps (Fig. 3): (1) pre-treatment of the precursors, including mixing and grinding, if required; (2) shaping of the precursor into blocks, e.g. by (hydraulic) compaction; and (3) $\mathrm{CO}_{2}$ curing in an autoclave (at elevated $\mathrm{CO}_{2}$ pressure) or in a climate chamber (at low $\mathrm{CO}_{2}$ pressure).

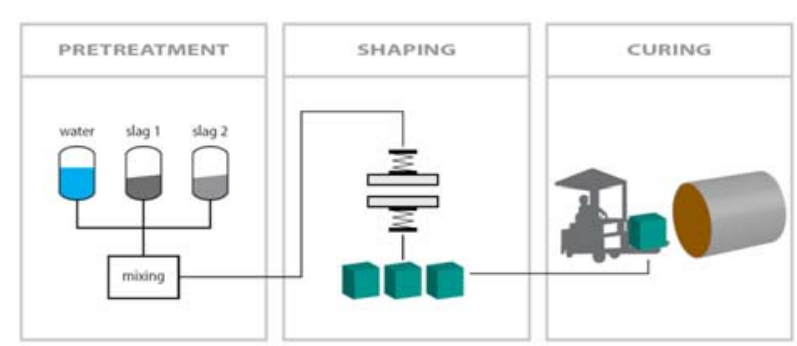

Figure 3. Schematic drawing of the accelerated carbonation process developed for stainless steel slag by [18].

In 1999 large porous blocks (1mx1mx1m) were made using only steelmaking slag and $\mathrm{CO}_{2}$ [44]. The blocks were produced by moist carbonation in an airtight mold. $\mathrm{CO}_{2}$ gas saturated in steam was injected through the bottom of the molds at a pressure of 1.03 atmosphere over a period of 12 days. The compressive strength of the resulting blocks reached $18 \pm 3 \mathrm{MPa}$. The blocks were carbonated homogeneously and the $\mathrm{CO}_{2}$ uptake was approximately $6 \%$ [44]. The NKK corporation (presently JFE steel) started marketing these blocks under the registered trade name Marine Blocks for constructing artificial reefs [52].

Subsequently, Quaghebeur et al. [35] produced stainless steel compacts that reached compressive strengths up to 55 $\mathrm{MPa}$ using pure $\mathrm{CO}_{2}$ at a pressure of $20 \mathrm{bar}$ and $140^{\circ} \mathrm{C}$. By optimizing the particle packing and compacting pressure EAF steel slag compacts $(300 \times 100 \times 50 \mathrm{~mm})$ were produced with compressive strengths up to $134 \mathrm{MPa}$ after carbonation and that complied to environmental leaching limit regulations [18]. The $\mathrm{CO}_{2}$ uptake was 10-15\%. Salman et al. [37] made similar compacts of AOD slag that reached compressive strengths of $34 \mathrm{MPa}$ after 3 weeks in a carbonation chamber at atmospheric pressure with $5 \% \mathrm{CO}_{2}$, and $59.8 \mathrm{MPa}$ after 15 hours in a carbonation reactor at 8 bar $\mathrm{CO}_{2}$ and $80^{\circ} \mathrm{C}$.

Recently, moist carbonation of steel slags was taken to the industrial scale by the DeRuwBouwGroep (DRBG) company for the production of pre-cast building blocks. The products consist of natural sand mixed with fine milled steel slag and are carbonated in a climate chamber at low pressure. The first products were released on the Dutch market early 2017.

\section{Conclusions and perspectives}

Different alkaline residues or waste materials can be used to make sustainable products for the construction industry by accelerated carbonation. Most studies on accelerated carbonation have focused on the carbonation efficiency and carbonation rate has been studied as a function of $\mathrm{L} / \mathrm{S}$ ratio, pressure, temperature, particle size, $\mathrm{CO}_{2}$ concentration and pressure. However, when the main goal is to produce valuable construction products that can compete with traditional construction materials, the technical properties, environmental impact and processing costs are at least as important as the carbonation rate and it has been noted that the highest $\mathrm{CO}_{2}$ conversion rates do not necessarily result in the highest compressive strengths.

Carbonation coupled with granulation also appears to be a promising treatment for permanently storing $\mathrm{CO}_{2}$ in solid form, obtaining a product (aggregate) that may be employed for civil engineering applications and also valorize different types of alkaline waste materials that are currently under utilized. Although, there are already full scale examples of application of this granulation process, some issues need to be further elucidated. In particular, the treatment time and the amount and type of waste materials and additives (cements or alkali activators) should be optimized in order to obtain a product presenting suitable mechanical properties and leaching behavior. Future studies will also need to assess the overall environmental, as well as economical, sustainability of these treatment processes as well as the net uptake of $\mathrm{CO}_{2}$ achieved.

At present few studies have focused on strength development, and factors such as microstructure development that affect strength are not as well investigated as factors affecting carbonation efficiency. Besides carbonation rate the compressive strength that can be gained by compacts through mineral carbonation also 
depends on compact size and shape, compaction force, particle packing and carbonate mineralogy.

One of the main challenges for accelerated carbonation is to obtain a $\mathrm{CO}_{2}$ gas stream at the carbonation site. In most lab studies high purity $\mathrm{CO}_{2}$ is used, which is costly. New efficient and low cost $\mathrm{CO}_{2}$ capturing technology may significantly lower these costs. Using flue gases or biogas directly or after a $\mathrm{CO}_{2}$ pre-concentration treatment can be a viable option, as long as these do not contain any constituents that may affect the $\mathrm{CO}_{2}$ uptake or mechanical performance of the carbonated compacts.

\section{References}

[1] Gartner E, Hirao H (2015) A review of alternative approaches to the reduction of $\mathrm{CO} 2$ emissions associated with the manufacture of the binder phase in concrete. Cement and Concrete Research 78:126-142. https://doi.org/10.1016/j.cemconres.2015.04.012

[2] Biernacki JJ, Bullard JW, Sant G, Brown K, Glasser FP, Jones S, Ley T, Livingston R, Nicoleau L, Olek J (2017) Cements in the 21st Century: Challenges, Perspectives, and Opportunities. Journal of the American Ceramic Society 100 (7):2746-2773. https://doi.org/10.1111/jace.14948

[3] Lackner KS, Wendt CH, Butt DP, Joyce EL, Sharp DH (1995) Carbon dioxide disposal in carbonate minerals. Energy 20 (11):1153-1170. https://doi.org/10.1016/0360-5442(95)00071-N

[4] Benyus JM (2002) Biomimicry: Innovation inspired by nature. Perennial New York,

[5] Bell FG (1993) Durability of carbonate rock as building stone with comments on its preservation. Environmental Geology 21 (4):187200. https://doi.org/10.1007/BF00775905

[6] Glasser FP, Marchand J, Samson E (2008) Durability of concrete Degradation phenomena involving detrimental chemical reactions. Cement and Concrete Research 38 (2):226-246. https://doi.org/10.1016/i.cemconres.2007.09.015

[7] Fernandez Bertos M, Simons SJ, Hills CD, Carey PJ (2004) A review of accelerated carbonation technology in the treatment of cement-based materials and sequestration of $\mathrm{CO} 2$. J Hazard Mater 112 (3):193-205. https://doi.org/10.1016/j.jhazmat.2004.04.019

[8] Klemm W, Berger R (1972) Accelerated curing of cementitious systems by carbon dioxide: Part I. Portland cement. Cement and Concrete Research 2 (5):567-576.

https://doi.org/10.1016/0008-8846(72)90111-1

[9] Young J, Berger R, Breese J (1974) Accelerated curing of compacted calcium silicate mortars on exposure to $\mathrm{CO} 2$. Journal of the american ceramic society 57 (9):394-397. https://doi.org/10.1111/j.1151-2916.1974.tb11420.x

[10] De Ceukelaire L, Van Nieuwenburg D (1993) Accelerated carbonation of a blast-furnace cement concrete. Cement and Concrete Research 23 (2):442-452. https://doi.org/10.1016/0008-8846(93)90109-M

[11] Galvez-Martos J, Morrison J, Jauffret G, Elsarrag E, AlHorr Y, Imbabi M, Glasser F (2016) Environmental assessment of aqueous alkaline absorption of carbon dioxide and its use to produce a construction material. Resources, Conservation and Recycling 107:129-141. https://doi.org/10.1016/i.resconrec.2015.12.008

[12] Glasser FP, Jauffret G, Morrison J, Galvez-Martos J-L, Patterson N Imbabi MS-E (2016) Sequestering CO2 by Mineralization into Useful Nesquehonite-Based Products. Frontiers in Energy Research 4:3. https://doi.org/10.3389/fenrg.2016.00003

[13] Morrison J, Jauffret G, Galvez-Martos JL, Glasser FP (2016) Magnesium-based cements for $\mathrm{CO} 2$ capture and utilisation. Cement and Concrete Research 85:183-191. https://doi.org/10.1016/i.cemconres.2015.12.016

[14] Cizer Ö, Rodriguez-Navarro C, Ruiz-Agudo E, Elsen J, Van Gemert D, Van Balen K (2012) Phase and morphology evolution of calcium carbonate precipitated by carbonation of hydrated lime. Journal of Materials Science 47 (16):6151-6165 https://doi.org/10.1007/s10853-012-6535-7
[15] Vance K, Falzone G, Pignatelli I, Bauchy M, Balonis M, Sant G (2015) Direct carbonation of $\mathrm{Ca}(\mathrm{OH}) 2$ using liquid and supercritical CO2: Implications for carbon-neutral cementation. Industrial \& Engineering Chemistry Research 54 (36):8908-8918. https://doi.org/10.1021/acs.iecr.5b02356

[16] Ashraf W, Olek J (2016) Carbonation behavior of hydraulic and non-hydraulic calcium silicates: potential of utilizing low-lime calcium silicates in cement-based materials. Journal of materials science 51 (13):6173-6191. https://doi.org/10.1007/s10853-016-9909-4

[17] Johnson D, MacLeod C, Carey P, Hills C (2003) Solidification of stainless steel slag by accelerated carbonation. Environmental technology 24 (6):671-678. https://doi.org/10.1080/09593330309385602

[18] Quaghebeur M, Nielsen P, Horckmans L, Van Mechelen D (2015) Accelerated Carbonation of Steel Slag Compacts: Development of High-Strength Construction Materials. Frontiers in Energy Research 3:12. https://doi.org/10.3389/fenrg.2015.00052

[19] Baciocchi R, Costa G, Di Bartolomeo E, Polettini A, Pomi R (2010) Carbonation of Stainless Steel Slag as a Process for CO2 Storage and Slag Valorization. Waste and Biomass Valorization 1 (4):467477. https://doi.org/10.1007/s12649-010-9047-1

[20] Pan S-Y (2012) CO2 Capture by Accelerated Carbonation of Alkaline Wastes: A Review on Its Principles and Applications. Aerosol and Air Quality Research. https://doi.org/10.4209/aaqr.2012.06.0149

[21] Elenova S (2010) Reduction of CO2 emissions by mineral carbonation: steelmaking slags as raw material with a pure calcium carbonate end product., Aalto University, Espoo, Finland

[22] Teir S, Eloneva S, Fogelholm C-J, Zevenhoven R (2006) Stability of calcium carbonate and magnesium carbonate in rainwater and nitric acid solutions. Energy Conversion and Management 47 (1819):3059-3068. https://doi.org/10.1016/i.enconman.2006.03.021

[23] Zevenhoven R, Fagerlund J, Songok JK (2011) CO2 mineral sequestration: developments toward large-scale application. Greenhouse Gases: Science and Technology 1 (1):48-57. https://doi.org/10.1002/ghg3.7

[24] Papadakis V, Fardis M, Vayenas C (1992) Effect of composition, environmental factors and cement-lime mortar coating on concrete carbonation. Materials and Structures 25 (5):293-304. https://doi.org/10.1007/BF02472670

[25] Morandeau A, Thiery M, Dangla $P$ (2014) Investigation of the carbonation mechanism of $\mathrm{CH}$ and $\mathrm{CSH}$ in terms of kinetics, microstructure changes and moisture properties. Cement and Concrete Research 56:153-170. https://doi.org/10.1016/j.cemconres.2013.11.015

[26] Fattuhi N (1988) Concrete carbonation as influenced by curing regime. Cement and Concrete Research 18 (3):426-430. https://doi.org/10.1016/0008-8846(88)90076-2

[27] Cui H, Tang W, Liu W, Dong Z, Xing F (2015) Experimental study on effects of $\mathrm{CO} 2$ concentrations on concrete carbonation and diffusion mechanisms. Construction and Building Materials 93:522-527. https://doi.org/10.1016/j.conbuildmat.2015.06.007

[28] Sahu S, DeCristofaro N (2013) Solidia Cement. In: Solidia Technol. White Pap.

[29] Brent GF, Petrie JG (2008) CO2 sequestration by mineral carbonation in the Australian context. Chemeca 2008: Towards a Sustainable Australasia:1273

[30] Fernández Bertos M, Li X, Simons SJR, Hills CD, Carey PJ (2004) Investigation of accelerated carbonation for the stabilisation of MSW incinerator ashes and the sequestration of $\mathrm{CO} 2$. Green Chem 6 (8):428-436. https://doi.org/10.1039/B401872A

[31] Johnson D (2000) Accelerated carbonation of waste calcium silicate materials, vol $108 / 2000$. Society of Chemical Industry Science Lecture Series,

[32] Huijgen WJ, Witkamp G-J, Comans RNJ (2005) Mineral CO2 sequestration by steel slag carbonation. Environmental Science \& Technology 39:9676-9682. https://doi.org/10.1021/es050795f

[33] lizuka A, Katsuyama Y, Fujii M, Yamasaki A, Yanagisawa Y (2004) Development of a new carbon dioxide sequestration scenario by the carbonation of waste cement. Prepr Pap-Am Chem Soc, Div Fuel chem 49 (1)

[34] Uibu M, Kuusik R, Andreas L, Kirsimäe K (2011) The CO2 -binding by Ca-Mg-silicates in direct aqueous carbonation of oil shale ash 
and steel slag. Energy Procedia 4:925-932.

https://doi.org/10.1016/j.egypro.2011.01.138

[35] Quaghebeur M, Nielsen P, Laenen B, Nguyen E, Van Mechelen D (2010) Carbstone: sustainable valorisation technology for fine grained steel slags and CO2. Refractories worldforum 2 (2):75-79

[36] Wu HZ, Chang J, Pan ZZ, Cheng X Effects of carbonation on steel slag products. In: Advanced Materials Research, 2011. Trans Tech Publ, pp 485-488

[37] Salman M, Cizer Ö, Pontikes Y, Santos RM, Snellings R, Vandewalle L, Blanpain B, Van Balen K (2014) Effect of accelerated carbonation on AOD stainless steel slag for its valorisation as a CO2-sequestering construction material. Chemical Engineering Journal 246:39-52. https://doi.org/10.1016/i.cej.2014.02.051

[38] Huijgen WJ, Comans RN (2006) Carbonation of Steel Slag for CO2 Sequestration: Leaching of Products and Reaction Mechanisms. Environ Sci Technol 40:2790-2796.

https://doi.org/10.1021/es052534b

[39] Suer P, Lindqvist J-E, Arm M, Frogner-Kockum P (2009) Reproducing ten years of road ageing-Accelerated carbonation and leaching of EAF steel slag. Science of the total environment 407 (18):5110-5118

https://doi.org/10.1016/j.scitotenv.2009.05.039

[40] van Zomeren A, van der Laan SR, Kobesen HB, Huijgen WJ, Comans RN (2011) Changes in mineralogical and leaching properties of converter steel slag resulting from accelerated carbonation at low CO2 pressure. Waste Manag 31 (11):22362244. https://doi.org/10.1016/j.wasman.2011.05.022

[41] Last GV, Schmick MT (2015) A review of major non-power-related carbon dioxide stream compositions. Environmental Earth Sciences 74 (2):1189-1198. https://doi.org/10.1007/s12665-015-4105-4

[42] Abatzoglou N, Boivin S (2009) A review of biogas purification processes. Biofuels, Bioproducts and Biorefining 3 (1):42-71. https://doi.org/10.1002/bbb.117

[43] Isoo T, Takahashi T, Fukuhara M (2001) Using carbonated steelmaking slag blocks to help reduce $\mathrm{CO} 2$. American Ceramic Society Bulletin 80 (1):73-75.

[44] Isoo T, Takahashi T, Okamoto N, Fukuhara M (2000) Development of large steelmaking slag blocks using a new carbonation process. Advances in Cement Research 12 (3):97-101.

https://doi.org/10.1680/adcr.2000.12.3.97

[45] Chang EE, Pan SY, Yang L, Chen YH, Kim H, Chiang PC (2015) Accelerated carbonation using municipal solid waste incinerator bottom ash and cold-rolling wastewater: Performance evaluation and reaction kinetics. Waste Manag 43:283-292.

https://doi.org/10.1016/j.wasman.2015.05.001

[46] Gunning PJ, Hills CD, Carey PJ (2009) Production of lightweight aggregate from industrial waste and carbon dioxide. Waste Manag 29 (10):2722-2728. https://doi.org/10.1016/j.wasman.2009.05.021

[47] Gunning P, Hills C, Antemir A, Carey P Novel approaches to the valorisation of ashes using aggregation by carbonation. In: Proceedings of the 2nd International Slag Valorisation Symposium, Leuven, Belgium, 2011. pp 18-20.

[48] Morone M, Costa G, Polettini A, Pomi R, Baciocchi R (2014) Valorization of steel slag by a combined carbonation and granulation treatment. Minerals Engineering 59:82-90. https://doi.org/10.1016/j.mineng.2013.08.009

[49] Librandi P, Costa G, de Souza ACB, Stendardo S, Luna AS, Baciocchi $R$ (2017) Carbonation of Steel Slag: Testing of the Wet Route in a Pilot-scale Reactor. Energy Procedia 114:5381-5392. https://doi.org/10.1016/j.egypro.2017.03.1674

[50] Carbon8 (2017) Technology - adding carbon dioxide to waste to give it commercial value. http://c8s.co.uk/technology/.

[51] Morone M, Costa G, Georgakopoulos E, Manovic V, Stendardo S, Baciocchi R (2017) Granulation-carbonation treatment of alkali activated steel slag for secondary aggregates production. Waste and Biomass Valorization 8 (5):1381-1391. https://doi.org/10.1007/s12649-016-9781-0

[52] Takahashi T, Yabuta K (2002) New Application of Iron and Steelmaking Slag. NKK Technical Report-Japanese Edition-:43-48. 